\title{
Morphological Diversity of Farmers' and Improved Potato (Solanum tuberosum) Cultivars Growing in Eritrea
}

\author{
Biniam M. Ghebreslassie ${ }^{1,2}$, S. M. Githiri ${ }^{2}$, Tadesse M. ${ }^{1}$ \& Remmy W. Kasili ${ }^{3}$ \\ ${ }^{1}$ Department of Horticulture, Hamelmalo Agricultural College, Eritrea \\ ${ }^{2}$ Department of Horticulture, Jomo Kenyatta University of Agriculture and Technology, Nairobi, Kenya \\ ${ }^{3}$ Institute of Biotechnology Research, Jomo Kenyatta University of Agriculture and Technology, Nairobi, Kenya \\ Correspondence: Biniam M. Ghebreslassie, Department of Horticulture, Hamelmalo Agricultural College, \\ Eritrea; Department of Horticulture, Jomo Kenyatta University of Agriculture and Technology, Nairobi, Kenya. \\ E-mail: bm95913@yahoo.com
}

Received: March 1, 2016 Accepted: March 30, 2016 Online Published: June 28, 2016

doi:10.5539/jps.v5n2p63 URL: http://dx.doi.org/10.5539/jps.v5n2p63

\begin{abstract}
Farmers' and improved potato (Solanum tuberosum L.) cultivars growing in Eritrea are main sources of food and income to many growers. The current study was proposed to characterize 17 farmers' and 4 imported cultivars of potato using 33 morphological descriptors. Planting was done in two geographically distinct locations, HAC and Asmara, Eritrea. The experiment was laid out in a randomized complete block design with three replications having 18 plants per plot. Plants grown at HAC emerged early (24.52 days) and reach maturity ( 94.84 days) while at Asmara it took 43.77 and 123.59 days, respectively. However, yield was higher in Asmara (0.49 $\mathrm{kg} / \mathrm{plant})$ compared to $\mathrm{HAC}(0.37 \mathrm{~kg} / \mathrm{plant})$. An accession having many and longer stems was associated with more tuber production, but inversely related to yield. Similarly, accessions with higher stem thickness and tuber size were associated with high yields. The PCA analysis indicated that the first four components explained about $85 \%$ of the total variability among the studied materials. The PCA clustered the materials in to four main groups (GI, GII, GIII, GIV) mainly explained by flowering patterns and yield related descriptors. The work has provided useful information on morphological characteristics of the farmer's potato to avoid duplication of resources and identify promising materials for future breeding program.
\end{abstract}

Keywords: diversity, Eritrea, morphological characterization, potato, principal component

\section{Introduction}

Potato cultivation has long history in Eritrea, however, little is known about their diversity. Understanding the genetic diversity of a species can assist in the analysis of the taxonomic structure of potential breeding populations for crop improvement (Afuape, Okocha, \& Njoku, 2011). The correct identification of a cultivar can be used to certify its pureness as an accession (Rosa, de Campos, de Sousa, Sforça, Torres, \& de Souza, 2010); although many cultivars share the same traits.

A number of methods are currently available for characterization including pedigree, morphology, agronomic performance, biochemical, and molecular (DNA-based) data (Mohammadi \& Prasanna, 2003). The typical approach to variety identification involves the observation and recording of morphological characters or descriptors (Nováková, Šimáčková, Bárta, \& Čurn, 2010). Morphological assessment is based on phenotypic characteristics of a plant species that determine diversity and similarity between and within populations. These descriptors are traits such as leaf type, tuber shape and flower colour which can be analyzed during different developmental stages of the crop. According to Fongod, Mih, \& Nkwatoh (2012) morphological descriptors could be suitable for use in distinguishing accessions. Several studies using morphological descriptors have been conducted on potato (Ahmadizadeh \& Felenji, 2011; Arslanoglu, Aytac, \& Oner, 2011; Felenji, Aharizad, Afsharmanesh, \& Ahmadizadeh, 2011) and other crops e.g. sweet potato (Afuape et al., 2011; Fongod, Mih \& Nkwatoh, 2012; Tairo, Mneney, \& Kullaya, 2008), chilli (Del, Perez, Alvarez, Arrazate, Damian, \& Lomeli, 2007), peanut (Upadhyaya, Ortiz, Bramel, \& Singh, 2003), or rice (Gana, Shaba, \& Tsado, 2013; Sinha \& Mishra, 2013). 
Few researches have been conducted to study the genetic diversity of potato materials growing in Eritrea. Landrace potato varieties are widely known by names based on their flower colour or place of origin/cultivation such as Carneshim, Israel, Shashemanie, Asela, America etc. Similar naming and duplication problem was reported by Tairo et al. (2008) in sweet potatoes growing in Tanzania. This makes it difficult and complicated to collect, identify and classify cultivars while avoiding duplication as many local names are conferred to the same cultivars and vice versa. The authors added that, varied cultivar naming system limits the proper identity of the cultivar and follow up in the field. Moreover, lack of accurate varietal identification limits conducting and/or evaluating varietal performance to select and improve suitable farmer-preferred varieties. For that reason, large study was carried out to assess diversity among potato accessions growing in Eritrea using morphological traits; this paper reports on the growth performance, correlation matrix between the variables, principal component analysis (PCA) and bi-plot while in another paper cluster analysis employing singe linkage and mean deviation of each group from the average was reported. The finding provided information on the basic characteristics of potato landraces and varieties growing in Eritrea to identify and avoid duplication of resources. The finding will also be resource information for breeders for future crop improvement strategy to increase productivity of potato in Eritrea.

\section{Materials and Methods}

\subsection{Plant Materials}

A total of 21 potato accessions collected from farmers and National Agricultural Research Institute (NARI) were used (Table A-1). The tubers from framers were freshly harvested while from NARI were stored for some time but not sprouted. The tuber seeds were allowed to sprout and later the same number and type of plant materials were planted in two locations under farmers' conditions to determine morphological similarity and diversity among themselves. The first site was located at the experimental field of Hamelmalo Agricultural College (HAC) with an altitude of about $1330 \mathrm{~m}$ above sea level with $15^{\prime} 53 \mathrm{~N}$ and $38^{\prime} 26 \mathrm{E}$ coordinates. Since the crop is adapted to cool seasons, planting was done towards the end of winter when the temperature is relatively low. The second site was located in the high land (Asmara) with $2363 \mathrm{~m}$ above sea level altitude and 15'20N and 38'56E coordinates. The chemical property of the soil in both sites was analyzed in the soil laboratory of the National Agricultural Research Institute (NARI) Halhale (Biniam, Githiri, Tadesse, \& Kasili, 2015).

The experiment was laid out in a randomized complete block design (RCBD) with three replications. Planting was made in furrows at inter- and intra-row spacings of 0.70 and $0.40 \mathrm{~m}$, respectively. Three rows and six tubers per row (18 plants per plot) and 63 plots per site was used. At planting time, Di-ammonium Phosphate (DAP) fertilizer was applied at the rate of $200 \mathrm{~kg} / \mathrm{ha}$. One month after emergence, Urea fertilizer was applied at the rate of $150 \mathrm{~kg} / \mathrm{ha}$. A total of 33 descriptors (14 vegetative; 6 flowering and 13 reproductive) were used (Table 1).

Table 1 . The vegetative, flowering and reproductive descriptors used in this study

\begin{tabular}{lll}
\hline Vegetative & \multicolumn{1}{c}{ Flowering } & \multicolumn{1}{c}{ Reproductive } \\
\hline Days to emergence (Emer_DAP) & Days to flowering (Flow_DAP) & Tuber diameter/size (T_size) \\
Emergence \% (Emer_\%) & No of flowers per plant (No_flow) & Primary tuber Skin color (PTSC) \\
No of primary stems (No PS) & Primary Flower Color (PFC) & Intensity of primary skin color (IPSC) \\
Stem color (SC) & Secondary Flower Color (SFC) & Secondary tuber skin color (STSC) \\
No of interjected leaf lets (No inter leaf) & Distribution of SFC ( Diss. SFC) & Distribution of STSC (Diss_STSC) \\
No of lateral leaf lets (No later leaf) & Flower degree (Flow_dg) & Primary Tuber Flesh Color (PTFC) \\
Plant Height (PH) & & Secondary Tuber Flesh Color (STFC) \\
Stem Thickness (ST) & & Tuber shape (T_shape) \\
Stem Wing (SW) & & Tuber Eye Depth (T_ED) \\
Growth Habit (GH) & & Skin texture (S_texture) \\
Branching Habit (BH) & & Tuber set (T_set) \\
Primary Sprout Colour (PSC) & Tuber weight (T_wt) \\
Secondary Sprout Colour (SSC) & Maturity time (Maturity) \\
Distribution of SSC (Diss. SSC) & & \\
\hline
\end{tabular}


Data for morphological traits were recorded as per the descriptors reported by Huaman, Williams, Salhuana and Vincent (1977). The qualitative morphological characters were performed by numerical coding of each character, whereas for the quantitative traits, data collection was performed using measurement. In case of quantitative data, analysis of ANOVA was carried out to determine any significant variation among the accessions. Standardization of the data by means of the coefficient matrix function was made and then subjected to multivariate analysis of correlation coefficient, PCA and bi-plot analysis using SPSS (ver. 20) and GenStat (12 ed). The phenotypic correlation coefficient (r) values were calculated to measure the relationship between two sets of variables and correlation matrix was generated. Eigen values, percent variance, variance and cumulative percentage of each of the extracted factors were calculated and PCA analysis done on the basis of major factors.

\section{Results}

\subsection{Plant Growth Characteristics}

The data collected from the field in both sites indicated that there was a significant effect of location (environment) on the growth and performance of the plants. Data collected on the emergence date, plant branching habit, days to flowering, No of flowers, No of primary stems, stem thickness, growth habit, leaf interject, number of lateral leaves, maturity time and over all yield quality and quantity showed significant difference between the two regions (Table 2). The table showed that materials grown in HAC took fewer days to emerge (24.52) and reach maturity (94.84) as compared to plants grown in Asmara (43.77) and (123.59) days, respectively. Despite that, yield weight was higher at Asmara as compared to HAC (Table 2). Mean average of all the parameters in the two sites was used to calculate the PCA, coefficient matrix and bi-plot to minimize environmental effect. It was noted that plants grown in the high altitude (Asmara) failed and/or were late to produce flowers, the effect of photoperiod.

The separate cluster analysis of the landraces and varieties grown at Asmara and Hemelmalo generated each three groups at $84 \%$ similarity level. There was no sharp relationship in grouping of the materials in the two locations (Table 3).

Table 2. Statistical summary of the variables showed significant difference between the sites

\begin{tabular}{llllll}
\hline Variables & Site & \multicolumn{4}{l}{ Statistical summary } \\
\cline { 2 - 6 } & HAC & Asmara & Mean & LSD & St Dv. \\
\hline Emergence Date & 24.52 & 43.77 & 33.66 & $0.96^{* *}$ & 5.13 \\
Branching Habit & 1.07 & 1.40 & 1.23 & $0.09^{* *}$ & 0.50 \\
Growth Habit & 1.57 & 1.84 & 1.75 & $0.11^{* *}$ & 0.35 \\
Stem Thickness & 8.22 & 8.68 & 8.40 & $0.34^{*}$ & 1.24 \\
No. of Primary Stems & 3.23 & 2.30 & 2.78 & $0.27^{* *}$ & 1.06 \\
Flowering Date & 41.07 & 73.74 & 57.01 & $1.95^{* *}$ & 29.40 \\
No. of Flowers & 2.30 & 1.86 & 2.03 & $0.12^{* *}$ & 1.29 \\
Leaf interject & 1.68 & 2.00 & 1.84 & $0.04 * *$ & 0.39 \\
No. of lateral eaves & 4.03 & 3.94 & 3.99 & $0.08^{*}$ & 0.52 \\
Maturity time & 94.84 & 123.59 & 108.30 & $1.84^{* *}$ & 9.49 \\
Tuber set & 8.35 & 9.85 & 8.99 & $0.83^{* *}$ & 4.89 \\
Tuber Size & 38.00 & 40.20 & 39.42 & $1.21^{* *}$ & 6.64 \\
Tuber weight & 0.37 & 0.49 & 0.43 & $0.04 * *$ & 0.17 \\
\hline
\end{tabular}

$\mathrm{LSD}=$ Least Significant Difference; StDv. = standard deviation; ** highly significant at $<0.01$; * significant at $<0.05$ 
Table 3. Growth performance characteristic of the studied potato landraces and improved varieties in two geographically different locations (ASM and HAC)

\begin{tabular}{|c|c|c|c|c|c|c|c|c|c|c|c|c|c|c|c|c|}
\hline \multirow[t]{2}{*}{ Plant Material } & \multicolumn{8}{|c|}{ Asmara } & \multicolumn{8}{|c|}{ HAC } \\
\hline & PH & ST & $\begin{array}{l}\text { No } \\
\text { PS }\end{array}$ & $\begin{array}{l}\text { T_wt } \\
\text { (Kg/plt) }\end{array}$ & $\begin{array}{l}\text { Tuber } \\
\text { set/plt }\end{array}$ & $\begin{array}{l}\text { T_Size } \\
\text { (cm) }\end{array}$ & $\begin{array}{l}\text { Maturity } \\
\text { (Days) }\end{array}$ & $\begin{array}{l}\text { Cluster } \\
\text { Grouping }\end{array}$ & PH & ST & $\begin{array}{l}\text { No } \\
\text { PS }\end{array}$ & $\begin{array}{l}\text { T_wt } \\
\text { (Kg/plt) }\end{array}$ & $\begin{array}{l}\text { Tuber } \\
\text { set/plt }\end{array}$ & T_Size & $\begin{array}{l}\text { Maturity } \\
\text { (Days) }\end{array}$ & $\begin{array}{l}\text { Cluster } \\
\text { Grouping }\end{array}$ \\
\hline Yeha & 22.1 & 7.5 & 3.5 & 0.311 & 14.08 & 31.0 & 132.0 & GI & 28.1 & 7.8 & 5.3 & 0.386 & 15.17 & 35.1 & 92.3 & GI \\
\hline Tsaeda Embaba I & 23.1 & 7.6 & 3.1 & 0.328 & 19.42 & 27.3 & 131.0 & GI & 28.7 & 8.0 & 5.3 & 0.304 & 14.25 & 32.5 & 94.3 & GI \\
\hline Keyh_Embaba_I & 16.4 & 6.9 & 1.7 & 0.163 & 6.00 & 34.3 & 116.3 & GI & 16.4 & 6.1 & 2.2 & 0.105 & 5.50 & 32.2 & 72.0 & GIII \\
\hline Tsaeda_Embab_II & 24.8 & 8.2 & 4.3 & 0.472 & 18.67 & 30.3 & 132.0 & GI & 27.6 & 7.4 & 5.6 & 0.384 & 13.33 & 34.5 & 92.7 & GI \\
\hline Carneshim & 22.2 & 10.8 & 2.0 & 1.050 & 6.92 & 56.8 & 126.7 & GI & 25.8 & 10.6 & 3.5 & 0.671 & 6.42 & 52.6 & 92.7 & GII \\
\hline Shashemanie_I & 22.2 & 7.0 & 3.3 & 0.506 & 18.58 & 32.7 & 133.3 & GI & 33.0 & 7.7 & 5.3 & 0.406 & 13.08 & 40.0 & 93.0 & GI \\
\hline Zafira_I & 20.6 & 7.4 & 1.8 & 0.364 & 6.67 & 39.4 & 122.3 & GIII & 20.9 & 8.0 & 3.1 & 0.408 & 6.67 & 43.3 & 90.0 & GII \\
\hline Round_Sudan & 21.5 & 9.5 & 1.3 & 0.363 & 6.50 & 40.8 & 108.7 & GI & 12.8 & 9.2 & 1.2 & 0.363 & 5.33 & 41.8 & 95.0 & GII \\
\hline Oval_Sudan & 22.5 & 11.0 & 2.1 & 0.413 & 6.83 & 38.4 & 128.3 & GIII & 22.1 & 9.7 & 2.7 & 0.254 & 4.75 & 32.7 & 84.7 & GII \\
\hline Keyh_Embaba_II & 33.1 & 8.2 & 3.0 & 0.642 & 17.00 & 36.2 & 106.7 & GII & 35.9 & 7.6 & 5.5 & 0.560 & 16.00 & 34.1 & 89.0 & GI \\
\hline Tsaeda_Embaba_III & 23.3 & 11.4 & 1.6 & 0.816 & 7.33 & 52.3 & 124.7 & GI & 22.5 & 9.8 & 2.0 & 0.633 & 7.50 & 41.4 & 95.67 & GII \\
\hline Banba & 19.5 & 8.1 & 2.5 & 0.788 & 7.08 & 50.6 & 126.0 & GI & 19.8 & 8.2 & 2.2 & 0.292 & 4.50 & 41.4 & 111.0 & GII \\
\hline Baren & 17.6 & 8.8 & 2.6 & 0.386 & 7.00 & 42.5 & 126.0 & GI & 16.3 & 9.3 & 2.4 & 0.393 & 4.83 & 40.4 & 117.7 & GII \\
\hline Orla & 19.3 & 7.5 & 2.6 & 0.236 & 5.50 & 38.7 & 113.7 & GIII & 18.2 & 8.9 & 1.8 & 0.205 & 4.75 & 36.5 & 92.3 & GII \\
\hline Slaney & 18.8 & 8.9 & 2.2 & 0.538 & 6.17 & 46.9 & 121.3 & GI & 16.3 & 9.2 & 3.8 & 0.351 & 5.00 & 38.8 & 114.7 & GII \\
\hline Shashemanie_II & 21.3 & 10.2 & 2.0 & 0.613 & 18.33 & 35.4 & 128.7 & GI & 36.2 & 7.9 & 4.3 & 0.560 & 18.33 & 38.1 & 93.0 & GI \\
\hline Keyh Embaba_III & 18.8 & 8.0 & 1.5 & 0.272 & 10.67 & 35.0 & 123.3 & GI & 11.1 & 4.6 & 2.2 & 0.148 & 7.17 & 20.0 & 62.3 & GII \\
\hline Ajeba & 18.3 & 7.0 & 2.7 & 0.357 & 7.23 & 38.7 & 99.3 & GII & 18.9 & 6.7 & 3.1 & 0.348 & 5.33 & 41.9 & 87.0 & GII \\
\hline Zafira_II & 22.3 & 10.1 & 1.4 & 0.622 & 4.25 & 53.6 & 128.0 & GIII & 18.2 & 9.9 & 1.8 & 0.362 & 5.67 & 39.6 & 115.0 & GII \\
\hline Safira & 20.9 & 7.4 & 2.3 & 0.286 & 4.75 & 42.0 & 117.3 & GI & 16.8 & 6.7 & 2.7 & 0.333 & 5.17 & 41.4 & 87.0 & GII \\
\hline Grandnain & 25.1 & 9.8 & 1.5 & 0.662 & 6.70 & 50.8 & 129.3 & GI & 15.6 & 8.5 & 1.8 & 0.341 & 5.00 & 41.0 & 116.3 & GII \\
\hline Grand mean & 21.6 & 8.6 & 2.3 & 0.492 & 9.79 & 40.7 & 122.6 & & 21.9 & 8.2 & 3.2 & 0.372 & 8.27 & 38.1 & 94.7 & \\
\hline LSD (5\%) & 5.1 & 1.5 & 0.8 & 0.210 & 4.21 & 5.9 & 6.20 & & 4.5 & 1.5 & 1.5 & 0.077 & 1.24 & 4.6 & 8.1 & \\
\hline
\end{tabular}

\subsection{Correlation Coefficient Matrix}

Pearson's correlation is a measure of strength of linear relationship between two variables (Sinha \& Mishra, 2013). Correlation coefficient analysis of the studied traits helped to decide how many traits to select and remove the ineffective ones. Out of the total 33 descriptors used, 16 exhibited significant contribution to explain variation among the accession and were used for further classification analysis. It was reported by Felenji et al. (2011) that the factors which justify more percentage of variations are importance for further study. The pair wise correlation among the identified 16 traits was thus generated (Table 4). The table shows positive and negative correlation between the variables along with their magnitude. Generally, all variables associated with flowering exhibited a strong relationship to each other.

On the other hand, Emergence day showed strong negative relation with growth habit and No. of primary stems where as strong positive with the stem thickness. Similarly, No of primary stem showed strong positive relation with plant height and tuber set. In other word, tuber set has strong positive correlation with No. of primary stem, plant height, flower degree but negative correlation with tuber weight and size. On the other hand, tuber weight was strongly correlated with the tuber size and stem thickness, while negatively correlated with tuber set (numbers). 
Table 4. Correlation coefficient matrix among the 16 descriptors of 21 accessions studied

\begin{tabular}{|c|c|c|c|c|c|c|c|c|c|c|c|c|c|c|c|}
\hline$\frac{\frac{0}{0}}{\frac{\sigma}{\pi}}$ & 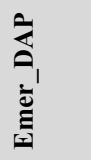 & 3 & 눈 & $\begin{array}{l}\tilde{\omega} \\
\stackrel{\mathbf{z}}{ }^{\prime}\end{array}$ & $\bar{a}$ & 乩 & $\begin{array}{l}\hat{a} \\
\vec{a} \\
\frac{\vec{a}}{\Sigma}\end{array}$ & $\frac{U}{\sqrt[r]{n}}$ & $\begin{array}{l}u \\
\tilde{n}_{1} \\
\ddot{n}\end{array}$ & 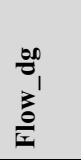 & $\begin{array}{l}\stackrel{z}{e} \\
e^{\prime}\end{array}$ & 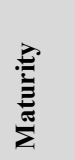 & $\begin{array}{l}\frac{\check{\Xi}}{\pi} \\
\frac{5}{n} \\
H^{\prime}\end{array}$ & $\begin{array}{l}\frac{\pi}{\omega} \\
-1\end{array}$ & $\begin{array}{l}\vec{\Phi}_{1} \\
\omega_{1} \\
H^{\prime}\end{array}$ \\
\hline SW & -0.22 & 1.00 & & & & & & & & & & & & & \\
\hline $\mathrm{GH}$ & -0.65 & 0.02 & 1.00 & & & & & & & & & & & & \\
\hline No_PS & -0.72 & 0.26 & 0.38 & 1.00 & & & & & & & & & & & \\
\hline $\mathrm{PH}$ & -0.38 & 0.06 & -0.05 & 0.74 & 1.00 & & & & & & & & & & \\
\hline ST & 0.62 & 0.20 & -0.54 & -0.29 & 0.09 & 1.00 & & & & & & & & & \\
\hline Flow_DAP & 0.28 & -0.01 & -0.15 & 0.12 & 0.12 & 0.04 & 1.00 & & & & & & & & \\
\hline SFC & 0.00 & -0.36 & -0.09 & 0.20 & 0.37 & -0.09 & 0.70 & 1.00 & & & & & & & \\
\hline Dis_SFC & 0.11 & -0.15 & -0.07 & 0.26 & 0.31 & -0.05 & 0.91 & 0.89 & 1.00 & & & & & & \\
\hline Flow_dg & -0.02 & -0.06 & 0.03 & 0.47 & 0.39 & -0.10 & 0.90 & 0.75 & 0.92 & 1.00 & & & & & \\
\hline No_flow & 0.16 & -0.06 & -0.04 & 0.35 & 0.29 & -0.02 & 0.90 & 0.64 & 0.88 & 0.95 & 1.00 & & & & \\
\hline Maturity & 0.29 & 0.27 & -0.09 & 0.10 & 0.08 & 0.50 & 0.31 & -0.01 & 0.18 & 0.22 & 0.25 & 1.00 & & & \\
\hline T_shape & 0.53 & 0.13 & -0.42 & -0.58 & -0.29 & 0.62 & -0.33 & -0.45 & -0.45 & -0.54 & -0.40 & 0.11 & 1.00 & & \\
\hline $\mathrm{T}_{-}$size & 0.41 & 0.12 & -0.39 & -0.43 & -0.17 & 0.63 & -0.15 & -0.17 & -0.26 & -0.37 & -0.33 & 0.34 & 0.79 & 1.00 & \\
\hline T_set & -0.49 & 0.02 & 0.19 & 0.82 & 0.82 & -0.23 & 0.39 & 0.49 & 0.53 & 0.67 & 0.56 & 0.04 & -0.69 & -0.56 & 1.00 \\
\hline T_wt & 0.09 & 0.13 & -0.37 & 0.12 & 0.50 & 0.63 & 0.14 & 0.24 & 0.15 & 0.13 & 0.05 & 0.33 & 0.37 & 0.67 & 0.16 \\
\hline
\end{tabular}

Where: Emer_DAP= emergence date after planting; $\mathrm{SW}=$ stem wing; $\mathrm{GH}=$ growth habit; No PS= number primary stem; $\mathrm{PH}=$ plant height; $\mathrm{ST}=$ stem thickness; Flow_DAP= flowering day after planting; SFC= secondary flower colour; Dis_SFC= distribution of SFC; Flow_dg= flowering degree; No_flow=number flowers per plant; $T_{-}=$tuber.

\subsection{Principal Component Analysis (PCA)}

Based on the initial Eigen value $\geq 1$ scored in the current study, four components were selected. The PCA gave comparable results in the two localities, however, the yield related parameters and PH were explained by PCA1

Table 5. PCA of the 16 morphological traits for 21 potato materials evaluated

\begin{tabular}{lllll}
\hline \multicolumn{1}{c}{ Variables } & \multicolumn{3}{c}{ Principal Components } \\
\cline { 2 - 5 } & $\mathbf{1}$ & $\mathbf{2}$ & $\mathbf{3}$ & $\mathbf{4}$ \\
\hline Emergence date after planting (Emer DAP) & 0.264 & 0.583 & -0.684 & -0.055 \\
Stem Wing (SW) & -0.156 & 0.011 & 0.147 & 0.814 \\
Growth Habit (GH) & -0.134 & -0.706 & 0.183 & 0.187 \\
No Primary Stems (No PS) & 0.183 & -0.337 & 0.843 & 0.257 \\
Plant Height (PH) & 0.205 & 0.177 & 0.914 & -0.051 \\
Stem thickness (ST) & 0.012 & 0.853 & -0.083 & 0.289 \\
Flowering days after planting (Flow DAP) & 0.963 & 0.050 & -0.060 & 0.114 \\
Secondary Flower Color (SFC) & 0.785 & 0.071 & 0.257 & -0.392 \\
Distribution of_SFC (Diss. SFC) & 0.958 & -0.005 & 0.144 & -0.085 \\
Flower degree (Flow_dg) & 0.936 & -0.115 & 0.269 & 0.065 \\
No of flowers per plant (No_flow) & 0.938 & -0.075 & 0.103 & 0.106 \\
Maturity & 0.287 & 0.348 & -0.030 & 0.692 \\
Tuber shape (T_shape) & -0.427 & 0.701 & -0.373 & 0.111 \\
Tuber size (T_size) & -0.270 & 0.813 & -0.180 & 0.161 \\
Tuber set (T_set) & 0.477 & -0.246 & 0.794 & -0.008 \\
Tuber weight/yield (T_wt) & 0.075 & 0.813 & 0.462 & 0.090 \\
Eigen-value/latent roots for each PC & 6.0 & 3.85 & 2.37 & 1.32 \\
Variation in Percentage (\%) for each PC & 37.50 & 24.08 & 14.08 & 8.25 \\
\hline
\end{tabular}


in HAC while by PCA2 in Asmara. Moreover, high percentage of variability was explained by the first four components in Asmara (84.08\%) as compared to HAC (80.58\%) when data were analyzed separately. When data were pooled off together, the first four components explain about $85 \%$ of the total variability. The identified traits contained in these components exhibited significantly on the morphological expression of the accessions. PCA1 with eigenvalue of 6.0 contributed $37.50 \%$ of variation among the observed 21 potato accessions. The traits accounted to this component are Flowering day, secondary flower colour (SFC), Distribution of SFC, Flower degree and No of flowers per plant (Table 5); PC2 with 3.85 eigenvalue contributed $24.08 \%$ of the total variation relating to tuber shape, tuber size, tuber weight, growth habit and stem thickness; PC3 was corresponding to Emergence day, plant height, No. of primary stem and tuber set (Table 5).

\subsection{Morphological Diversity}

A principal component bi-plot of the 21 accessions and the 16 traits were carried out to show the underlying relationships among the accessions, accessions with traits and between the traits. The 21 accessions on axes representing the two rotated components PCA1 and PCA2 indicated that the plants are distributed in the first three quadrants, while the traits are scattered in I, II and IV quadrants widely (Figure 1).The scatter plot matrix score clustered the materials into four main groups (GI, GII, GIII and GIV) (Figure 1). Group I consisting of eight farmers' materials predominantly with flowering (white and/or red) coloured. They are characterized by intermediate emergence and intermediate maturing with a more than two and long primary stems (Biniam et al., 2015). Whereas GII consists of nine materials mainly made up of varieties of late emerging and late maturing with few and short primary stems, but relatively better yield. This group is positively associated with $T$ _shape, T_size, T_wt, Maturity and Emer_DAP, while negatively related to GH, No_PS and T_set. GIII consists of three

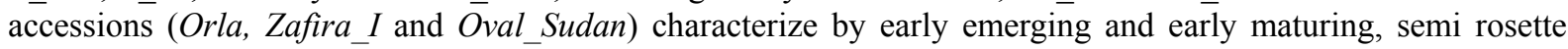
growth habit and intermediate yield quantity. Most of the materials in GII and GIII are characterized by non-flowering pattern. On the other hand, GIV is a single material (Ajiba) characterized by very early maturity and lower yield quantity. This classification is not in exact, but in accordance with the cluster analysis generated employing single linkage using the same data (Biniam et al., 2015).

\section{Principal Component Biplot}

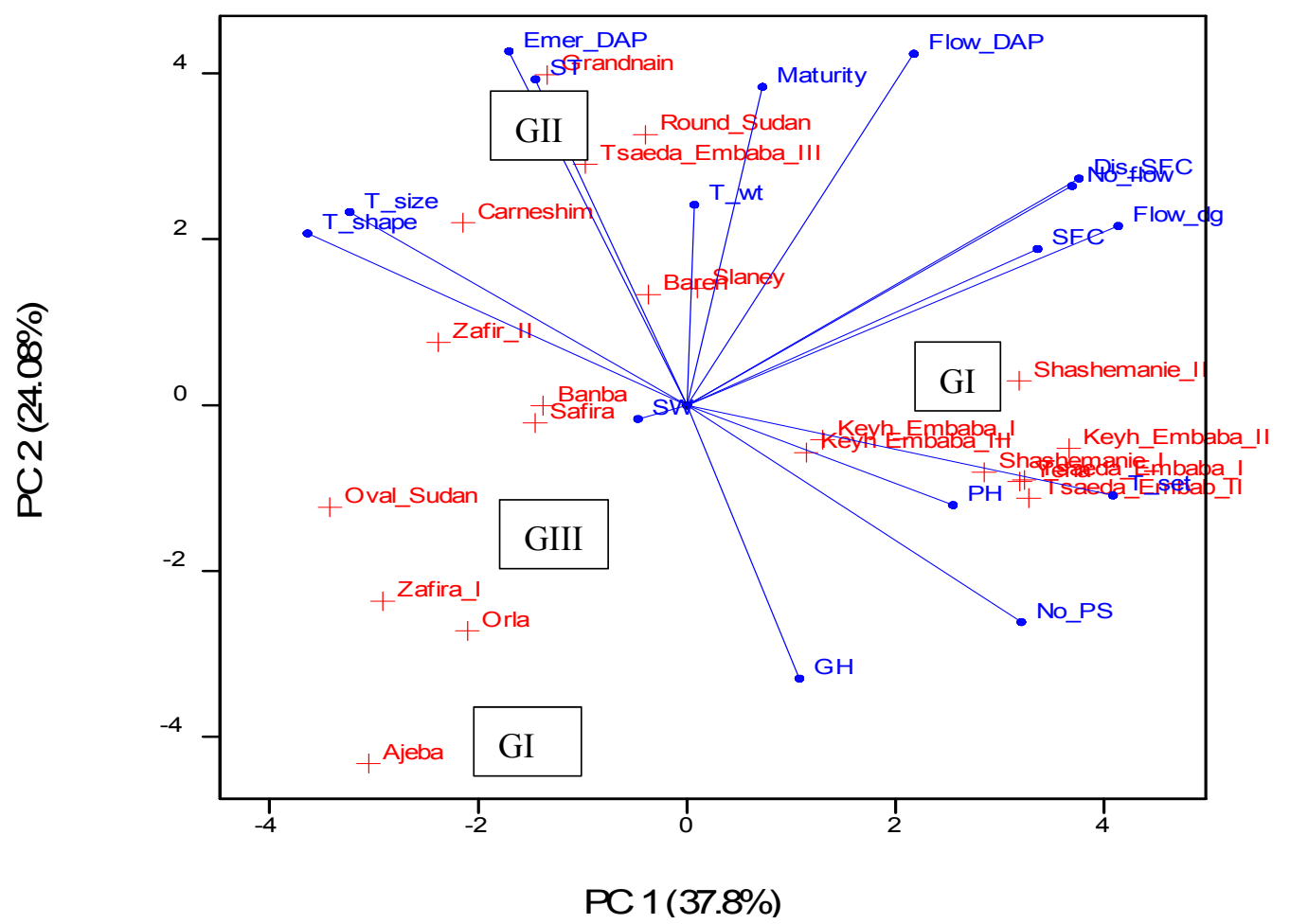

Figure 1. Scatter plot matrix of PC score of accessions and variables using of PCA1 and PCA2 


\section{Discussion}

The growth characteristics study revealed that growth performance of plants is strongly affected by the environment and soil type. According to Crawford (2000) morphological descriptors unlike the molecular markers are not free from environmental and pleotropic effects. This is attributed to the climatic condition of the two sites, where HAC is subtropical with higher mean temperature $\left(24^{\circ} \mathrm{C}\right)$ than Asmara $\left(16^{\circ} \mathrm{C}\right)$ that accelerates the growth rate at the cost of yield quality and quantity. It was reported by Waniale, Wanyera, and Talwana (2014) that there were significant differences in all quantitative traits measured among the Mungbean varieties planted in two different locations in Uganda for characterization.

The preliminary PCA of the studied traits helped to decide how many traits to select and remove the ineffective ones. It was reported by Felenji et al. (2011) that the factors which justify more percentage of variations are importance for further study. The identified traits showed positive and negative correlation to each other with few remaining independent. It can then be inferred from the result that an accession having more and longer stems is likely to produce more tubers, but usually inversely relate to yield or tuber weight. This agrees with previous finding by Felenji et al. (2011) and Ahmadizadeh \& Felenji (2011) where they observed positive correlation between number of stems, plant height and tuber numbers. Similarly, Rashidi (2009) reported that number of tubers has a high correlation with number of stems produced. Moreover, it was noted from the current study that accessions with higher stem thickness and tuber size are associated with high yields. This is in accordance with the report made by (Felenji et al., 2011).The negative correlation between tuber weight and tuber number is ascribed to the fact that the more number of the tubers per plant produced, the smaller the size of each, which can be related to the strong competition for resources. Previously, Felenji et al. (2011) drew the same conclusion out of their findings. According to Okii, Tukamuhabwa, Odong, Namayanja, Mukabaranga, Paparu, and Gepts (2014), it was inferred that the strong correlations between two traits allow to make simultaneous selections and use of the related traits interchangeably in crop breeding and selection.

PCA is a technique which identifies plant traits contributing to the most observed variation among accessions (Afuape et al., 2011; Ahmadizadeh \& Felenji, 2011; Felenji et al., 2011; Okii et al., 2014) which in turn assists selection of parent lines for breeding purposes. Moreover, Okii et al. (2014) reported that PCA-biplot demonstrates diagrammatically the genetic diversity pattern of germplasm based on their morphological characteristics. Yet, PCA scatter matrix can be used to identify the contribution of each morphological characteristic from the accessions to form group or cluster. This approach was used for grouping in various crops such as in wheat varieties (Malik, Sharma, Sharma, Kundu, Verma, Sheoran, Kumar, \& Chatrath, 2014); in sweet potato (Afuape et al., 2011); and in common bean (Okii et al., 2014). The current PCA-biplot clustered the materials in to four groups. Accessions falling in the same quadrant are assumed to be the same or closely related (Malik et al., 2014). If the accession located in the plot at an angle of $90^{\circ}$ then the two accessions have no close relationship. The fact that the accessions are clustered into four groups indicates that there is exploitable variability between the accessions for core planting material selection. Especially in GII, although some accessions like Banba and Safira showed close relationship, majority have very weak similarity as is shown from the plot. The PC bi-plot analysis, further, indicated that descriptors like ST, Emer_DAP, T_shape, T_set and most of the flowering pattern are placed at long vectors in the plot and explained most variation among the accessions compared to PH, T-wt and maturity. Descriptors that are in the same quadrant with $<90^{\circ}$ angle means they have very close positive relationship and vice versa. All the flowering patterns showed similar variation $\left(<90^{\circ}\right)$ with PH and T_set as well with maturity and T_wt. Similarly, accessions falling alongside of the trait are more explained by the respective character or trait. The plot, thus, will help to identify desired traits contained by each accession for further breeding activity.

\section{Conclusion}

The current study on characterization of potatoes using morphological traits is the first in its kind in Eritrea. The work has provided initial result how morphological descriptors employing multivariate analysis can be used to characterize and classify accessions. The PCA indicated that a total of $84.63 \%$ variation was explained by the first four components among the 21 accessions. The highest variation observed in PCA1 was mainly contributed by the flowering patterns while the PCA2 was attributed to the yield components. The morphological characters such as flowering patterns and yield components are thus found to be useful phenotypic markers for genetic diversity study. Four groups of accessions were identified using PC analysis. It was noted there was no sharp relationship between the accessions and geographic origin of the seeds. This is ascribed to the free movement of resources from one Zoba to other by farmers. The identified morphological characteristics contained by each accession will help to select accession based on their character for breeding program. 


\section{Acknowledgements}

The authors wish to acknowledge the Japanese International Cooperation Agency (JICA) for funding the research work as well as Hamelmalo Agricultural College (HAC) and Zoba Maekel Agricultural Research Unit for providing graciously land for the research. We are also grateful to Biosciences eastern and central Africa International Livestock Research Institute (BecA-ILRI) Hub for financial support through the Africa Biosciences Challenge Fund Program (ABCF). The ABCF is funded by the Australian Department for Foreign Affairs and Trade (DFAT) through the BecA-CSIRO partnership; the Syngenta Foundation for Sustainable Agriculture (SFSA); the Bill \& Melinda Gates Foundation (BMGF); the UK Department for International Development (DFID) and; and the Swedish International Development Cooperation Agency (Sida). Last but not least, we sincerely thank Mr. Peter Willadsen, CSIRO for reviewing the paper and providing constructive comments.

\section{References}

Afuape, S. O., Okocha, P., \& Njoku, D. (2011). Multivariate Assessment of the Agromorphological Variability and Yield Components among Sweet Potato (Ipomoea batatas (L.) Lam) Landraces. African Journal of Plant Science, 5(2), 123-132.

Ahmadizadeh, M., \& Felenji, H. (2011). Evaluating Diversity among Potato Cultivars Using Agro-Morphological and Yield Components in Fall Cultivation of Jiroft Area. American-Eurasian Journal of Agricultural \& Environmental Sciences, 11(5), 655-662.

Arslanoglu, F., Aytac, S., \& Oner, E. K. (2011). Morphological Characterization of the Local Potato (Solanum tuberosum L.) Accessions Collected from the Eastern Black Sea Region of Turkey. African Journal of Biotechnology, 10(6), 922-932.

Biniam, M. G., Githiri, S. M., Tadesse, M., \& Kasili, R. W. (2015). Analysis of Diversity among Potato Accessions Grown in Eritrea Using Single Linkage Clustering. American Journal of Plant Sciences, 6, 2122-2127. http://dx.doi.org/10.4236/ajps.2015.613213

Crawford, D. J. (2000). Plant Molecular Systematics: Macromolecular Approaches. Wiley, New York.

Del, E., Perez, C. M., Alvarez, O. C., Arrazate, C. H. A., Damian, M. A. T. M., \& Lomeli, A. P. (2007). Morphological Variation in Guajillo Chili Pepper Plants (Capsicum annuum L.). African Crop Science Conference Proceedings, 8(99), 327-332.

Felenji, H., Aharizad, S., Afsharmanesh, G. R., \& Ahmadizadeh, M. (2011). Evaluating Correlation and Factor Analysis of Morphological Traits in Potato Cultivars Fall Cultivation of Jiroft Area. American-Eurasian Journal of Agricultural \& Environmental Sciences, 11(5), 679-684.

Fongod, A. G. N., Mih, A. M., \& Nkwatoh, T. N. (2012). Morphological and Agronomical Characterization of Different Accessions of Sweet Potatoes (Ipomoea batatas) in Cameroon. International Research Journal of Agricultural Science and Soil Science, 2(6), 234-245.

Gana, A. S., Shaba, S. Z., \& Tsado, E. K. (2013). Principal Component Analysis of Morphological Traits in Thirty-Nine Accessions of Rice (Oryza sativa L.) Grown in a Rainfed Lowland Ecology of Nigeria. Journal of Plant Breeding and Crop Sciences, 5, 120-126.

Huaman, Z., Williams, J. T., Salhuana, W., \& Vincent, L. (1977). Descriptors for the Cultivated Potato and for the Maintenance and Distribution of Germplasm Collections. AGPE: IBPGR/77/32. International Board For Plant Genetic Resources Rome, Italy.

Malik, R., Sharma, H., Sharma, I., Kundu, S., Verma, A., Sheoran, S., Kumar, R., \& Chatrath, R. (2014). Genetic Diversity of Agro-Morphological Characters in Indian Wheat Varieties Using GT biplot. Australian Journal of Crop Science, 8(9), 1266-1271.

Mohammadi, S. A., \& Prasanna, B. M. (2003). Review and Interpretation: Analysis of Genetic Diversity in Crop Plants-Salient Statistical Tools and Considerations. Crop Sciences, 43, 1235-1248. http://dx.doi.org/10.2135/cropsci2003.1235

Nováková, A., Šimáčková, K., Bárta, J., \& Čurn, V. (2010). Utilization of DNA Markers Based on Microsatellite Polymorphism for Identification of Potato Varieties Cultivated in the Czech Republic. Journal of Central European Agriculture, 11(4), 415-422. http://dx.doi.org/10.5513/JCEA01/11.4.854

Okii, D., Tukamuhabwa, P., Odong, T., Namayanja, A., Mukabaranga, J., Paparu, P., \& Gepts, P. (2014). Morphological Diversity Of Tropical Common Bean Germplasm. African Crop Science Journal, 22(1), 59-67. 
Rashidi, V. (2009). Effect of Plant Spacing and Seed Tuber Size on Yield and Yield Components of Potato Cultivars. Journal of Modern Science in Agriculture, 5(16), 19-26.

Rosa, P. M., de Campos, T., de Sousa, A. C. B., Sforça, D. A., Torres, G. A. M., \& de Souza, A. P. (2010). Potato Cultivar Identification Using Molecular Markers. http://dx.doi.org/10.1590/S0100-204X2010000100015

Sinha, A. K., \& Mishra, P. K. (2013). Morphology Based Multivariate Analysis of Phenotypic Diversity of Landraces of Rice (Oryza sativa L.) of Bankura District of West Bengal. Journal of Crop and Weed, 9(2), 115-121.

Tairo, F., Mneney, E., \& Kullaya, A. (2008). Morphological and Agronomical Characterization of Sweet potato [Ipomoea batatas (L.) Lam.] Germplasm Collection from Tanzania. African Journal of Plant Science, 2(8), 077-085.

Upadhyaya, H. D., Ortiz, R., Bramel, P. J., \& Singh, S. (2003). Development of a Groundnut Core Collection Using Taxonomical, Geographical and Morphological Descriptors. Genetic Resources and Crop Evolution, 50, 139-148. http://dx.doi.org/10.1023/A:1022945715628

Waniale, A., Wanyera, N., \& Talwana, H. (2014). Morphological and Agronomic Traits Variations for Mungbean Variety Selection and Improvement in Uganda. African Crop Science Journal, 22(2), 123-136.

\section{Appendix A}

Table A-1. List and source of potato genotypes used in this study

\begin{tabular}{rlllll}
\hline Accession No. & Common Name & Village & Subzoba & Zoba & Source \\
\hline 1 & Yeha & Geremi & Serejeka & Maekel & Farmers \\
2 & Tsaeda_Embaba_I & Afdeyu & Serejeka & Maekel & Farmers \\
3 & Keyh_Embaba_I & Afdeyu & Serejeka & Maekel & Farmers \\
4 & Tsaeda_Embab_II & Adiregit & Serejeka & Maekel & Farmers \\
5 & Carneshim & Adiregit & Serejeka & Maekel & Farmers \\
6 & Shashemanie_I & Mendefera & Mendefera & Debub & Farmers \\
7 & Zafira_I & SelaeDaero & Galanefhi & Maekel & Farmers \\
8 & Round_Sudan & SelaeDaero & Galanefhi & Maekel & Farmers \\
9 & Oval_Sudan & SelaeDaero & Galanefhi & Maekel & Farmers \\
10 & Keyh_Embaba_II & Debarwa & Debarwa & Debub & Famers \\
11 & Tsaeda_Embaba_III & Debarwa & Debarwa & Debub & Farmers \\
12 & Banba & Halhale & Debarwa & Debub & NARI \\
13 & Baren & Halhale & Debarwa & Debub & NARI \\
14 & Orla & Halhale & Debarwa & Debub & NARI \\
15 & Slaney & Halhale & Debarwa & Debub & NARI \\
16 & Shashemanie_II & Adi-Blay & Emnihaili & Debub & Farmers \\
17 & Keyh Embaba_III & Adi_mongonti & Mendefera & Debub & Farmers \\
18 & Ajeba & Adi mongonti & Mendefera & Debub & Farmers \\
19 & Zafir_II & Mendefera & Mendefera & Debub & Farmers \\
20 & Safira & Adilnadi & Mendefera & Debub & Farmers \\
21 & Grandnain & Adi-Mongonti & Mendefera & Debub & Farmers \\
\hline
\end{tabular}

\section{Copyrights}

Copyright for this article is retained by the author(s), with first publication rights granted to the journal.

This is an open-access article distributed under the terms and conditions of the Creative Commons Attribution license (http://creativecommons.org/licenses/by/3.0/). 